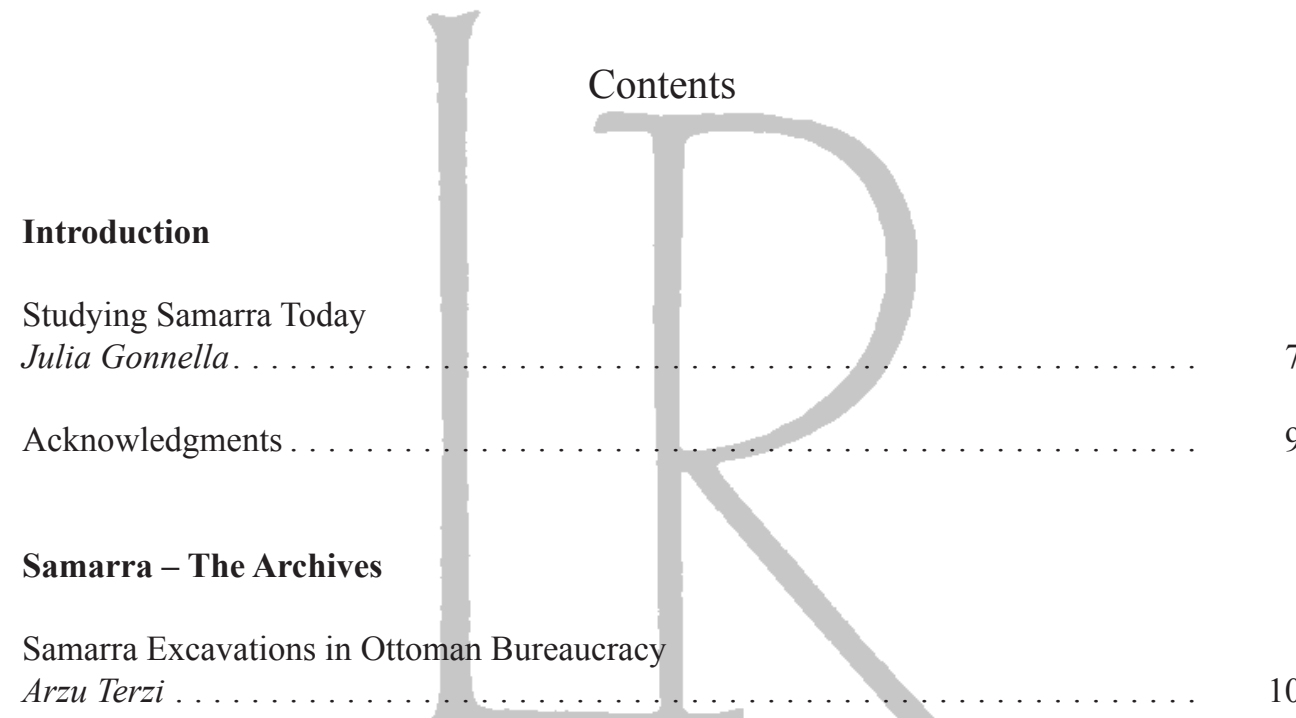

Excavations in the Archive. An Update on the Ernst Herzfeld Online Resources at the Freer|Sackler in Washington DC

Alexander Nagel, Rachael Woody.

The Samarra Finds in the New World:

Fragments of 'Abbasid Artistic Legacy in North American Museums

Yuka Kadoi .

\title{
Samarra - The City
}

'Askar al-Mu'tasim: the Central City of Samarra

Alastair Northedge.

Ibn Ṭulūn, al-Qatā'i and the Legacy of Samarra

Matthew S. Gordon

Samarra Today: the Present Situation of the Site and Studies

Alastair Northedge. .

\section{Samarra - The Finds}

The Painted Jars of Samarra: A Reconsideration

Fatma Dahmani.

Familiar Differences: Chinese Polychromes in the Indian Ocean Trade during the Ninth Century

Hsueh-man Shen 
Revisiting Samarra: the Rise of Islamic Glazed Pottery

Oliver Watson

Das Glas von Samarra unter Berücksichtigung neuer Glasfunde aus Syrien

Andrea Becker.

Zwei Tirazinschriften aus Samarra im historischen Kontext

Gisela Helmecke.

\section{Samarra - The Abbasid Province}

Abbasid Influence in Egypt? Archaeological Evidence from Elephantine and Abū Mīnā

Felix Arnold

Der Stuckdekor aus Kharab Sayyar: Die Motive, ihre Komposition und Gestaltung Angela Koppel.

Residential Architecture of the Darb Zubayda

Reconsidering the Dating of Qasr al-Mshatta Johannes Cramer, Barbara Perlich .

\section{Samarra - The Excavations}

Chronik der Ausgrabungen von Samarra 1911-1913.

Eine kulturhistorische Studie zur Forschungs- und Förderungsgeschichte der Islamischen Archäologie im 20. Jahrhundert Jens Kröger.

Notes on Contributors 